\title{
Calretinin immunoreactivity in the developing olfactory system of the rainbow trout
}

Authors:

Angel Porteros, Rosario Arévalo, Eduardo Weruaga, Carlos Crespo, Jesús

G. Briñón, José R. Alonso and José Aijón

Running title:

CR-IR in the developing olfactory system

Institutional affiliation:

Departamento de Biología Celular y Patología

Universidad de Salamanca

E-37007 Salamanca

Spain

Correspondence to be sent to:

Dr. José R. Alonso

Departamento de Biología Celular y Patología

Universidad de Salamanca

Facultad de Medicina

Avda. Campo Charro, 1

E-37007 Salamanca

Spain

Phone:(34) (23) 294400 ext. 1854

Fax: (34) (23) 294549

E-mail: jralonso@gugu.usal.es 


\section{ABSTRACT}

The distribution of calretinin immunoreactivity in the developing olfactory system of the rainbow trout was studied by using an indirect immunocytochemical method. Calretinin immunoreactivity was firstly detected at 150 day-degrees in the olfactory placode, where labeled primordial cells were observed. At 250 day-degrees, precursor cells of the olfactory receptor neurons located in the olfactory pit were calretininimmunoreactive. At 300 day-degrees, recognizable olfactory receptor neurons displayed calretinin immunoreactivity in the olfactory epithelium, and calretinin-immunopositive olfactory axons reached the presumptive olfactory bulb. After hatching (400 day-degrees) and during the subsequent development and maturation of the olfactory system, the number of calretinin-immunopositive olfactory receptor cells increased and distributed homogeneously throughout the olfactory epithelium. Accordingly, new positive olfactory fibers arrived to the olfactory bulb arborizing in olfactory glomeruli distributed in nine different terminal fields. Six days after hatching, calretinin-immunopositive interneurons within the olfactory bulb were also observed. The size and number of calretinin immunoreactive interneurons increased from this stage to adulthood. The adult pattern demonstrated both similarities and differences with the distribution of calretinin immunoreactivity previously described in the olfactory system of mammals. 


\section{KEY WORDS}

Anamniote, Calcium, Development, Fish, Immunocytochemistry, Olfactory receptor cells 


\section{INTRODUCTION}

The olfactory epithelium of vertebrates derives from the rostral thickening of the ectoderm, named the olfactory placode [17,18,22,33,40]. The receptor cell axons initially penetrate into the deep layers of the embryonic forebrain, where neurogenesis occurs, before retracting to their final positions in the superficial region of the olfactory bulb [25]. These axons induce the formation of the olfactory glomeruli [23] and the subsequent maturation of the olfactory bulb [21]. Within the glomeruli, olfactory axons synapse with second order elements known as mitral cells which are among the first to be established in the bulb [24].

In mammals, receptor neurons are segregated in different peripheral olfactory organs: the main olfactory epithelium, with majority of ciliated receptors, although scarce microvillar receptors have been described $[5,39,41,47]$; and the vomeronasal or Jacobson's organ with microvillous receptors, although a few ciliated receptors are also present[1,36]. Accordingly, two different brain targets, the main olfactory bulb and the accessory olfactory bulb receive segregated afferences from the olfactory epithelium and the vomeronasal organ in mammals. In teleosts, ciliated and microvillous olfactory receptor neurons are intermingled in the olfactory epithelium $[2,9,29,52]$. Although a regional segregation in the density of ciliated and microvillar receptors has been described in the olfactory rosettes [50], they are not situated in anatomicaly distinct organs and an accessory olfactory bulb is not present.

The olfactory bulb of teleosts posseses certain neuronal types (such as ruffed cells, perinest cells and mixed-synapse cells) and new neuronal 
circuits which have not been observed in other groups of vertebrates $[4,34,35]$. The axons of the mitral cells of teleosts project from the olfactory bulb to segregated central targets through two fiber pathways, the medial and the lateral olfactory tract $[10,15,20,48]$. In addition, recent studies indicate the presence in fish of extrabulbar projections from the olfactory epithelium to the ventral telencephalon and hypothalamus [14,27,43]. By contrast, only the lateral olfactory tract exists in mammals [3], and extrabulbar projections have not been described. All these findings indicate significative differences in the olfactory system between teleosts and mammals, suggesting a divergence in the evolution of their olfactory systems. Comparative neurochemical studies in species of these groups of vertebrates might provide new insights in the organization of the olfactory system.

Key processes during the development of the nervous system are calcium-dependent. Thus, calcium ions are involved in the folding of the neural plate and neurulation [7,38], in axon elongation [38], and in growing cone movements [31]. Therefore, the presence of calcium-buffering systems within olfactory receptor neurons is expected in order to maintain the appropriate levels of intracellular calcium necessary for these developmental processes.

Calretinin (CR) is a $29 \mathrm{kDa}$ calcium-binding protein of the EF-hand family that was first isolated from a chick retinal cDNA clone, and it shares $50-60 \%$ of the amino acid sequence with calbindin D-28k (CB) [44]. It has been proposed that these proteins are calcium-buffering systems that would protect neurons against calcium increases, during periods of high frequency discharge, or neurotransmitter-induced depolarization, or in pathological conditions [6,26,28,37]. CB- and CR-immunoreactivity have been described 
in the olfactory system of the adult mouse and rat $[11,16,30,32,42,46,51]$

and during the postnatal development of the rat $[12,13]$. Both proteins have been localized in olfactory receptor neurons and different subsets of interneurons of the olfactory bulb, while mitral cells expressed CR but were CB-immunonegative. No data are available on the distribution of these proteins in the embryonic development of the olfactory system of mammals or in the olfactory system of other vertebrates. In this work we analyze the evolution of the CR-immunolabeling in the olfactory system of the rainbow trout from prehatching stages of development to adulthood, and compare it with previous results in mammals in order to determine the possible divergence of the expression of this protein between teleosts and mammals.

\section{MATERIALS AND METHODS}

Fertilized eggs of rainbow trout Oncorhynchus mykiss (Walbaum, 1792) (Salmonidae, Teleostei) were obtained from a local breeder (Galisancho, Salamanca) and transferred to aquaria with fresh water at $10^{\circ} \mathrm{C}$ on a 12:12 hr light:dark cycle. After hatching, fry and juvenile rainbow trouts were kept under the same conditions. Since the factor of water temperature times the number of days until hatching, the developmental stages are given in day-degrees (dd) for embryos. This magnitude is obtained multiplying number of days after fertilization by water temperature. The developmental stages are given in days after hatching (D) for fry and juveniles. Three animals of each of the following stages were used: 150 dd, 200 dd, 250 dd, 300 dd, 350 dd, 3 D, 6 D, 21 D, 90 D and 180 D. Three adult (three years old) specimens weighing 150-300 g, were obtained from the same source and immediately processed. 


\section{Tissue preparation}

Animals were anesthetized with $0.03 \%$ tricaine methanesulphonate (MS-222 Sigma) and subsequently processed by different methods depending on their ages.

Young embryos (150 and 200 dd) were fixed by immersion in 4\% paraformaldehyde and 15\% saturated picric acid in $0.1 \mathrm{M}$ phosphate buffer, $\mathrm{pH} 7.4$ (PB) for $4 \mathrm{hr}$, washed in $\mathrm{PB}$ and processed whole mount for immunocytochemistry according to the avidin-biotin immunoperoxidase method.

Older embryos (250, 300, and 350 dd) and fry (3, 6 and 21 D) were fixed by immersion in 4\% paraformaldehyde and 15\% saturated picric acid in PB for 4 hr, washed in PB and immersed in 30\% sucrose (w/v) in PB for cryoprotection.

Juvenile (90 and 180 D) and adults (three years old) were perfused transcardially with $0.63 \% \mathrm{NaCl}$ solution followed by a fixative containing 4\% paraformaldehyde and 15\% saturated picric acid in PB. The brains were removed from the skull, postfixed in the same fixative for $4 \mathrm{hr}$ and immersed in PB containing 30\% sucrose (w/v) for cryoprotection.

Coronal and sagittal sections through the whole head of 250, 300 and 350 dd embryos, fry and juveniles, and through the brain of adults were cut at $20 \mu \mathrm{m}$ on a Leica cryostat, thawmounted on chrome alum-gelatinized slides and processed for immunocytochemistry following the avidin-biotinperoxidase method. 


\section{Immunocytochemistry}

Tissue was preincubated with $10 \%$ normal goat serum and $0.1 \%$ (1\% for whole mount preparations) Triton X-100 in PB for 1 hr (1 day for whole mount procedure) at $4^{\circ} \mathrm{C}$. Thereafter, the tissue was incubated with anti-CR serum (1:10,000 in PB) for two days (four days for whole mount procedure) at $4^{\circ} \mathrm{C}$. After washing in $\mathrm{PB}$, tissue was incubated with biotinylated goat anti-rabbit immunoglobulin G (Vector Labs., Burlingame USA; 1:200 in PB) for $1 \mathrm{hr}$ (12 hr for whole mount procedure) at room temperature and then in avidin-peroxidase complex (Vector Labs; 1:225 in PB) for 2 hr (16 hr for whole mount procedure). Tissue-bound peroxidase was visualized by incubating the sections with 0.07\% 3,3'-diaminobenzidine (Sigma) and $0.003 \% \mathrm{H}_{2} \mathrm{O}_{2}$ in $0.1 \mathrm{M}$ Tris-HCl buffer ( $\mathrm{pH}$ 7.6). The course of the reaction was controlled under the microscope. After rinsing with PB, sections were dehydrated through a graded alcohol series, cleared with xylene, and coverslipped using Entellan (Merck). Whole mount processed embryos were covered with glycerin jelly and coverslipped. Cell sizes were measured using a Zeiss ocular micrometer.

\section{Controls}

The primary anti-CR antibody used has been fully characterized $[44,45]$ and previously used in mammalian $[42,46]$ and teleost $[8]$ brain. The immunostaining procedure was controlled by omitting the primary antibody. Endogenous peroxidase activity was blocked by the application of $0.3 \%$ hydrogen peroxide diluted in methanol for $30 \mathrm{~min}$ before the incubation with the primary antibody. 


\section{RESULTS}

In the rainbow trout olfactory system, the anti-CR antibody stained olfactory receptor cells and their axons projecting to the olfactory bulb from prehatching stages to the adult, while CR-immunoreactive cells in the olfactory bulb were observed in posthatching stages. Extrabulbar CRimmunopositive projections were not observed in any developmental stage studied.

After whole mount CR-immunocytochemistry of 150 dd stage embryos, primordial cells of the peripheral olfactory organ were observed in the ventral surface of the head of the rainbow trout embryo, forming the olfactory placode. Round or oval undifferentiated cells displayed CR-like immunoreactivity in this olfactory structure (Fig. 1). At the $200 \mathrm{dd}$ stage, the CR-labeled cells in the olfactory placode showed the same morphological features but their number had increased.

At the 250 dd stage, the olfactory placode lost the direct contact with the embryonic forebrain and folded slightly forming a groove-like structure named the olfactory pit. Some CR-immunopositive cells were observed in the central portion of this structure. These cells were still morphologically undifferentiated, slightly stained, and their cell bodies were columnar (Fig. 2a).

At the following stage studied, $300 \mathrm{dd}$, recognizable olfactory receptors could be observed, and CR-immunoreactive axons arising from the dorsoventral pole of the olfactory pit could be followed towards the developing olfactory bulb (Fig. 2b). These CR-immunoreactive axons 
reached the ventral aspect of the embryonic forebrain and branched on the surface of the olfactory bulb, but they did not form proper glomeruli (Fig. 3a).

Hatching in the rainbow trout occurred approximately at 350-400 dd. After hatching, the olfactory system underwent a final maturation from larval stages to adulthood. In fry of 6 D, CR-immunopositive axons reached the olfactory bulb arborizing in small but well-defined glomeruli, round or elliptic in shape (Fig. 3b). In addition, CR-immunoreactive intrabulbar cells could be observed at this stage in the outermost aspect of the developing olfactory bulb (Fig. 3b, arrows). These cells were round and piriform, small (about $6 \mu \mathrm{m}$ of maximum diameter) and stained neurites were not evident.

Progressively, the olfactory epithelium raised in a complicated series of folds, called the olfactory rosette. At the stage of $21 \mathrm{D}$, olfactory receptor cells in all areas of this epithelium exhibited CR immunoreactivity (Fig. 2c). These cells had piriform perikarya and CR-immunopositive thin apical processes that thickened in their apical portion forming the olfactory knob (Fig. 4a). Axons originating from the basal portion of the olfactory receptor cells were difficult to identify, but sometimes the initial portion of the axon hillock could be distinguished (Fig. 4b). CR-immunoreactive olfactory axon bundles could be followed at the bottom of the olfactory epithelium (Fig 2c, arrows). These bundles aggregate into the olfactory nerve and coursed through the developing skull to the olfactory bulb (Fig. 2d).

At the stage of $90 \mathrm{D}$, the organization of the olfactory projections to the bulb in segregated terminal fields could be distinguished. At this age, anterior medial, ventral medial, dorsal lateral, lateral, ventral posterior lateral, ventral posterior, and posterior lateral fields could be identified (Fig. 
3c-f). The number of intrinsic CR-immunopositive cells increased, although stained prolongations were still not evident. At the following stage, $180 \mathrm{D}$, we observed a more complex organization in terminal fields at different levels throughout the olfactory bulb. Two additional terminal fields: dorsal posterior medial and dorsal posterior lateral were evident at this stage.

In adult trouts, the olfactory bulbs received the innervation of CRimmunopositive olfactory fibers, which coursed peripherally and arborized in the glomerular layer. This layer is thinner in the medial region of the olfactory bulbs and extends more caudally in the ventrolateral region than in the dorsomedial region. The nine terminal fields previously mentioned were clearly observed in serial coronal sections of the mature olfactory bulb (Fig. 5). In addition, we could observe CR-immunoreactive mature neurons in the boundary between the glomerular and plexiform layers of the olfactory bulb (Fig. 4c). These cells were small, about $9 \mu \mathrm{m}$ of maximum diameter, and only one stained dendrite arising from the somata was evident (Fig. 4d). According to these morphological features, these cells were identified as granule cells. Other neuronal types within the olfactory bulb did not display CR immunoreactivity.

\section{DISCUSSION}

Our results demonstrate that CR is distributed in the fish olfactory system from early prehatching developmental stages to adulthood. Previous studies demonstrated the presence of this calcium-binding protein in the olfactory system of the mouse and the rat [11-13,30,32,42,46,51]. During the postnatal development of the rat olfactory system, CR-immunostained olfactory receptor cells distributed throughout the olfactory mucosa and CRimmunoreactive cells in the olfactory bulb (both interneurons and output 
neurons) were detected at postnatal day $1[12,13]$. CR-immunopositive olfactory fibers within the olfactory bulb of the rat were firstly detected at postnatal day 5 [12]. These developmental studies on the distribution of CR in the olfactory system of mammals have been focused in postnatal stages, and no data are available about the prenatal expression of CR in both the olfactory epithelium and the olfactory bulb.

Our results in the rainbow trout showed an onset of the CR expression in a very early stage during the embryonic development at 150 dd, just after the formation of the olfactory placode [53]. We also observed the expression of CR during the sequence of appearance of the olfactory axons (at the $250 \mathrm{dd}$ stage) and dendrites (at the $300 \mathrm{dd}$ stage) that leaded to the maturation of ciliated receptors [53]. In the olfactory bulb only a subpopulation of granule cells displayed CR-immunoreactivity from the 6D stage. The late appearance of CR-immunoreactive granule cells coincided in time with the late maturation of the olfactory glomeruli, as described previously [14].

In the rat olfactory system, the adult pattern of CR immunoreactivity is acquired by postnatal day $20[12,13]$. In the adult rat, most of the olfactory receptor cells, olfactory axons and glomeruli, periglomerular cells, different cellular types in the external plexiform layer, mitral cells and granule cells of the olfactory bulb were CR-immunopositive $[11,30,42,46,51]$ suggesting a general involvement of this calcium-binding protein in the modulation of the olfactory signal. Our results showed CR immunoreactivity in the olfactory receptor cells of the adult rainbow trout, which suggests the involvement of CR in the calcium-buffering mechanism of growing axons during receptor turnover in both amniotes and anamniotes. By contrast, only a subpopulation of granule cells were CR- 
immunostained in the rainbow trout olfactory bulb, and other intrinsic neuronal types including mitral cells were CR-immunonegative, suggesting a restricted role for CR in the bulbar modulation.

Using antibodies against calmodulin, CB and CR, a topographical segregation of the expression of these calcium-binding proteins among the olfactory nerve bundles has been described [11]. CR was always localized in the internal portion of nerve bundles near the olfactory mucosa, and in small and external fascicles close to the olfactory bulb. Based on these findings, these authors have proposed an organization model relevant to odor discrimination.

Several studies showed a spatial segregation of the olfactory afferences in different terminal fields in the trout olfactory bulb [14,43], and this parcellation has been related to the functional segregation described after electrophysiological studies $[19,49]$. Thus, amino acids elicited greater responses in a region that might correspond with the dorsal lateral field, while the responses to bile salts were greater in the region that might correspond with the anterior medial field $[43,49,50]$. We have identified these terminal fields after CR-immunocytochemistry, and all of them were homogeneous with respect to the CR-immunostaining.

The existence of extrabulbar projections from the olfactory receptor cells to extrabulbar regions of the trout brain has been previously demonstrated $[14,27,43]$. In all the developmental stages studied we did not observe the presence of CR-immunostained extrabulbar components of the olfactory projection in either the telencephalon or the hypothalamus, which 
indicated a neurochemical heterogeneity of these projections with respect to the main pathway from the olfactory mucosa to the olfactory bulb.

\section{ACKNOWLEDGMENTS}

The authors thank Dr. J. Rogers (Cambridge, U.K.) for kindly providing the anti CR-antibody used in this study. This work was supported by funds from the DGICyT (PB94-1388) and the Junta de Castilla y León. 


\section{REFERENCES}

1. Adams, D. and Wiekamp, M.D., The canine vomeronasal organ, $J$. Anat., 138 (1984) 771-787.

2. Akeson, R.A., Primary olfactory neuron subclasses. In F.L. Margolis and T.V. Getchell (Eds.), Molecular Neurobiology of the Olfactory System, Plenum Press, New York and London, 1988, pp. 297-318.

3. Allison, A.C., The morphology of the olfactory system in the vertebrates, Biol. Rev., 28 (1953) 195-244.

4. Alonso, J.R., Lara, J., Miguel, J.J. and Aijón, J., Ruffed cells in the olfactory bulb of freshwater teleosts. I. Golgi impregnation, J. Anat., 155 (1987) 101-107.

5. Andres, K.H., Der olfaktorische Saum der Katze, Z. Zellforsch. mikrosk. Anat., 105 (1969) 107-122.

6. Andressen, C., Blümcke, I. and Celio, M.R., Calcium-binding proteins: selective markers of nerve cells, Cell Tissue Res., 271 (1993) 181-208.

7. Anglister, L., Farber, I.C., Shahar, A. and Grinvald, A., Localization of voltage-sensitive calcium channels along developing neurites: their possible role in regulating neurite elongation, Dev. Biol., 94 (1982) 351-365. 
8. Arévalo, R., Alonso, J.R., Porteros, A., Briñón, J.G., Crespo, C., Lara, J. and Aijón, J., Calretinin-like immunoreactivity in the optic tectum of the tench (Tinca tinca L.), Brain Res., 671 (1995) 112-118.

9. Bannister, L.H., The fine structure of the olfactory surface of teleostean fishes, Q. J. Microsc. Sci., 106 (1965) 333-342.

10. Bass, A.H., Olfactory bulb efferents in the channel catfish, Ictalurus punctatus, J. Morphol., 169 (1981) 91-111.

11. Bastianelli, E. and Pochet, R., Distribution of calmodulin, calbindinD28k and calretinin among rat olfactory nerve bundles, Neurosci. Lett., 169 (1994) 223-226.

12. Bastianelli, E. and Pochet, R., Calmodulin, calbindin-D28k, calretinin and neurocalcin in rat olfactory bulb during postnatal development, Dev. Brain Res., 87 (1995) 224-227.

13. Bastianelli, E., Polans, A.S., Hidaka, H. and Pochet, R., Differential distribution of six calcium-binding proteins in the rat olfactory epithelium during postnatal development and adulthood, J. Comp. Neurol., 354 (1995) 395-409.

14. Becerra, M., Manso, M.J., Rodríguez-Moldes, I. and Anadón, R., Primary olfactory fibers project to the ventral telencephalon and preoptic region in trout (Salmo trutta): a developmental immunocytochemical study, J. Comp. Neurol., 342 (1994) 131-143. 
15. Braford, M.R.J. and Northcutt, R.G., Olfactory bulb projections in the bichir, Polypterus., J. Comp. Neurol., 156 (1974) 165-178.

16. Briñón, J.G., Alonso, J.R., Arévalo, R., García-Ojeda, E., Lara, J. and Aijón, J., Calbindin D-28k-positive neurons in the rat olfactory bulb, Cell Tissue Res., 269 (1992) 289-297.

17. Brunjes, P.C. and Frazier, L.L., Maturation and plasticity in the olfactory system of vertebrates, Brain Res. Rev., 11 (1986) 1-45.

18. Cuschieri, A. and Bannister, L.H., The development of the olfactory mucosa in the mouse: light microscopy, J. Anat., 119 (1975) 277-286.

19. Doving, K.B., Selset, R. and Thommesen, G., Olfactory sensitivity to bile salts in salmonid fishes, Acta Physiol. Scand., 108 (1980) 123-131.

20. Dubois-Dauphin, M., Doving, K.B. and Holley, A., Topographical relation between the olfactory bulb and the olfactory tract in tench (Tinca tinca L.), Chem. Senses, 5 (1980) 159-169.

21. Gong, Q. and Shipley, M.T., Evidence that pioneer olfactory axons regulate telencephalic cell cycle kinetics to induce the formation of the olfactory bulb, Neuron, 14 (1995) 91-101.

22. Graziadei, P.P.C. and Monti Graziadei, G.A., Neurogenesis and neuron regeneration in the olfactory system of mammals. I. Morphological aspects of differentiation and structural organization of the olfactory sensory neurons, J. Neurocytol., 8 (1979) 1-8. 
23. Graziadei, P.P.C. and Monti Graziadei, A.G., Neuronal changes in the forebrain of mice following penetration by regenerating olfactory axons, J. Comp. Neurol., 247 (1986) 344-356.

24. Hinds, J.W., Autoradiographic study of histogenesis in the mouse olfactory bulb. II. Cell proliferation and migration, J. Comp. Neurol., 134 (1968) 305-322.

25. Hinds, J.W., Early neuron differentiation in the mouse olfactory bulb. II. Electron microscopy, J. Comp. Neurol., 146 (1972) 253-276.

26. Hof, P.R., Nimchinsky, E.A., Celio, M.R., Bouras, C. and Morrison, J.H., Calretinin immunoreactive neocortical interneurons are unaffected in Alzheimer's disease, Neurosci. Lett., 152 (1993) 145149.

27. Honkanen, T. and Ekström, P., An immunocytochemical study of the development of the olfactory system in the three-spined stickleback (Gasterosteus aculeatus L., Teleostei), Anat. Embryol., 184 (1991) 469-477.

28. Iacopino, A.M., Quintero, E.M. and Miller, E.K., Calbindin D-28k: a potential neuroprotective protein, Neurodegeneration, 3 (1994) 1-20.

29. Ichikawa, M. and Ueda, K., Fine structure of the olfactory epithelium in the goldfish, Carassius auratus. A study of retrograde degeneration, Cell Tissue Res., 183 (1977) 445-455. 
30. Jacobowitz, D.M. and Winsky, L., Immunocytochemical localization of calretinin in the forebrain of the rat, J. Comp. Neurol., 304 (1991) 198-218.

31. Kennedy, M.B., Regulation of neuronal function by calcium, Trends Neurosci., 12 (1989) 417-420.

32. Kishimoto, J., Keverne, E.B. and Emson, P.C., Calretinin, calbindinD28k, and parvalbumin-like immunoreactivity in mouse chemoreceptor neurons, Brain Res., 610 (1993) 325-329.

33. Klein, S.L. and Graziadei, P.P.C., The differentiation of the olfactory placode in Xenopus laevis: a light and electron microscopy study, $J$. Comp. Neurol., 217 (1983) 17-30.

34. Kosaka, T. and Hama, K., Presence of the ruffed cell in the olfactory bulb of the catfish, Parasilurus asotus, and the sea eel, Conger myriaster, J. Comp. Neurol., 193 (1980) 103-117.

35. Kosaka, T. and Hama, K., Synaptic organization in the teleost olfactory bulb, J. Physiol. (Paris), 78 (1982) 707-719.

36. Luckhaus, G., Licht und elektronenmikroskopische befunde an der Lamina epithelialis des Vomeronasalorgans vom Kaninchen, Anat. Anz., 124 (1969) 477-489.

37. Lukas, W. and Jones, K.A., Cortical neurons containing calretinin are selectively resistant to calcium overload and excitotoxicity in vitro, Neuroscience, 61 (1994) 307-316. 
38. Mattson, M.P., Taylor-Hunter, A. and Kater, S.B., Neurite outgrowth in individual neurons of a neuronal population is differentially regulated by calcium and cyclic AMP, J. Neurosci., 8 (1988) 17041711.

39. Menco, B.P.M., Qualitative and quantitative freeze-fracture studies on olfactory and nasal respiratory structures of frog, ox, rat, and dog. I. A general survey, Cell Tissue Res., 207 (1980) 183-209.

40. Mendoza, A.S., Breipohl, W. and Miragall, F., Cell migration from the chick olfactory placode: a light and electron microscopic study, $J$. Embryol. Exp. Morphol., 69 (1982) 47-59.

41. Moran, D.T., Rowley, J.C.I. and Jafek, B.W., Electron microscopy of human olfactory epithelium reveals a new cell type: the microvillar cell, Brain Res., 253 (1982) 39-46.

42. Résibois, A. and Rogers, J.H., Calretinin in rat brain: an immunohistochemical study, Neuroscience, 46 (1992) 101-134.

43. Riddle, D.R. and Oakley, B., Immunocytochemical identification of primary olfactory afferents in rainbow trout, J. Comp. Neurol., 324 (1992) 575-589.

44. Rogers, J.H., Calretinin: a gene for a novel calcium-binding protein expressed principally in neurons, J. Cell Biol., 105 (1987) 1343-1353. 
45. Rogers, J.H., Two calcium-binding proteins mark many chick sensory neurons, Neuroscience, 31 (1989) 697-709.

46. Rogers, J.H. and Résibois, A., Calretinin and calbindin D-28k in rat brain: patterns of partial co-localization, Neuroscience, 51 (1992) 843865.

47. Rowley, J.C.I., Moran, D.T. and Jafek, B.W., Peroxidase backfills suggest the mammalian olfactory epithelium contains a second morphologically distinct class of bipolar sensory neuron: the microvillar cell, Brain Res., 502 (1989) 387-400.

48. Scalia, F. and Ebbesson, S.O.E., The central projections of the olfactory bulb in a teleost (Gymnothorax funebris), Brain Behav. Evol., 4 (1971) 376-399.

49. Thommesen, G., The spatial distribution of odor induced potentials in the olfactory bulb of char and trout (Salmonidae), Acta Physiol. Scand., 102 (1978) 205-217.

50. Thommesen, G., Morphology, distribution and specificity of olfactory receptor cells in salmonid fishes, Acta Physiol. Scand., 117 (1983) 241-250.

51. Wouterlood, F.G. and Härtig, W., Calretinin-immunoreactivity in mitral cells of the rat olfactory bulb, Brain Res., 682 (1995) 93-100. 
52. Yamamoto, M., Comparative morphology of the peripheral olfactory organ in teleosts. In T.J. Hara (Eds.), Chemoreception in Fishes, Elsevier, Amsterdam, 1982, pp. 39-60.

53. Zielinski, B. and Hara, T.J., Morphological and physiological development of olfactory receptor cells in rainbow trout (Salmo gairdneri) embryos, J. Comp. Neurol., 271 (1988) 300-311. 


\section{FIGURE LEGENDS}

\section{Figure 1}

Whole mount CR immunocytochemistry in a 150 dd embryo.Ventral view. CR-immunoreactive spherical cells (arrows) are observed in the central region of the olfactory placode (OP), located rostral and slightly ventral to the eye. Scale bar $=100 \mu \mathrm{m}$

\section{Figure 2}

CR immunolabeling in the developing olfactory epithelium and olfactory nerve. Scale bar in a, c=100 $\mu \mathrm{m}$; in b, $d=50 \mu \mathrm{m}$. a) CRimmunoreactive columnar cells are distributed in the central portion of the pseudostratified epithelium, mainly in the upper region. Stage $250 \mathrm{dd}$ b) CR-immunolabeled axons run through the basal region of the olfactory pit forming the developing olfactory nerve (ON). Stage $250 \mathrm{dd}$. c) Coronal section through the olfactory epithelium of a $21 \mathrm{D}$ fry. CR-immunopositive olfactory receptor cells are widely distributed. Bundles of CRimmunoreactive axons cross the lamina propria (arrows). d) CRimmunopositive bundles of olfactory axons converging in the olfactory nerve. $21 \mathrm{D}$ fry.

\section{Figure 3}

CR-immunoreactivity during the development of the olfactory bulb. Scale bar in $\mathrm{a}=25 \mu \mathrm{m}$; in $\mathrm{b}=50 \mu \mathrm{m}$; in $\mathrm{c}-\mathrm{f}=100 \mu \mathrm{m}$. 
a) Detail of the embryonic telencephalon. CR-immunoreactive axons reach the ventral aspect of the telencephalic hemisphere (TEL), which forms the primordial olfactory bulb (OB). Stage $300 \mathrm{dd}$. b) Coronal section through the head of a $6 \mathrm{D}$ fry. CR-immunolabeled cells (arrows) and CRimmunopositive axons arborizing in a glomerulus (G). c-f) Serial coronal sections (from rostral to caudal) through the olfactory bulbs of a $90 \mathrm{D}$ juvenile showing developing fields of CR-immunopositive glomeruli. AM: anterior medial field; DL: dorsal lateral field; L: lateral field; PL: posterior lateral field; VM: ventral medial field; VP: ventral posterior field; VPL: ventral posterior lateral field.

\section{Figure 4}

CR-immunoreactive elements in the olfactory system of the adult rainbow trout. Scale bar in $\mathrm{a}, \mathrm{b}=25 \mu \mathrm{m}$; in $\mathrm{c}=100 \mu \mathrm{m}$; in $\mathrm{d}=50 \mu \mathrm{m}$. a-b) High-power magnification of CR-immunopositive olfactory receptor cells. Apical dendrites and terminal knobs (white arrow), and initial portions of the axon (black arrow) are visualized. c) Olfactory glomeruli (G) and displaced granule cells (arrows) displaying CR-immunoreactivity in the olfactory bulb of the adult rainbow trout. d) Higher magnification of a CRimmunolabeled granule cell, with a single apical dendrite arising from the soma.

\section{Figure 5}

Sequential coronal sections (a is rostral, $\mathrm{f}$ is caudal) through the left olfactory bulb of an adult rainbow trout, showing the distribution of distinct CR-immunopositive terminal fields. Scale bar=500 $\mu \mathrm{m}$. AM: anterior medial field; DL: dorsal lateral field; DPL: dorsal posterior lateral field; 
DPM: dorsal posterior medial field L: lateral field; PL: posterior lateral field; VM: ventral medial field; VP: ventral posterior field; VPL: ventral posterior lateral field. 
OP
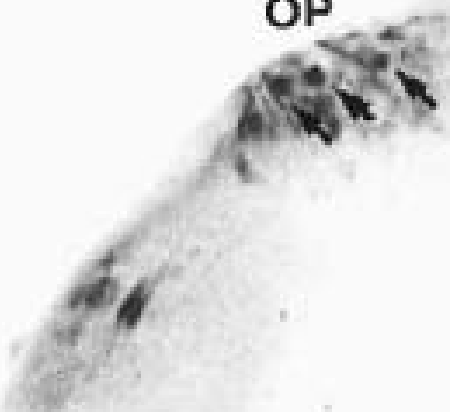


\section{a}

cartald id

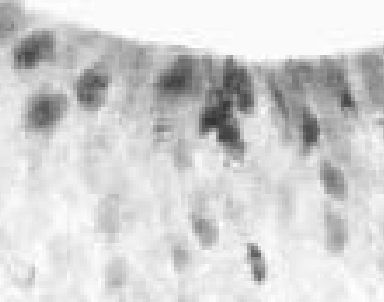

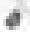

tove

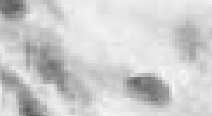

$y=$

c

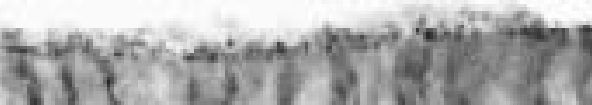

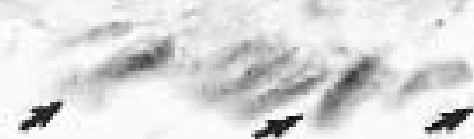

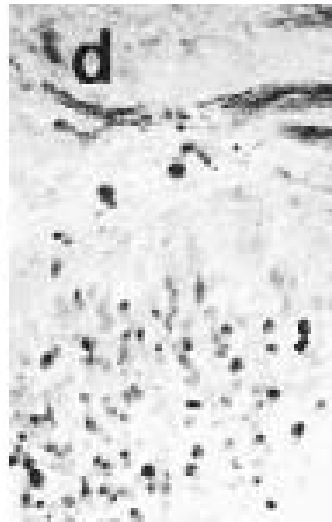

$x^{2}+\frac{1}{8} x^{2}$
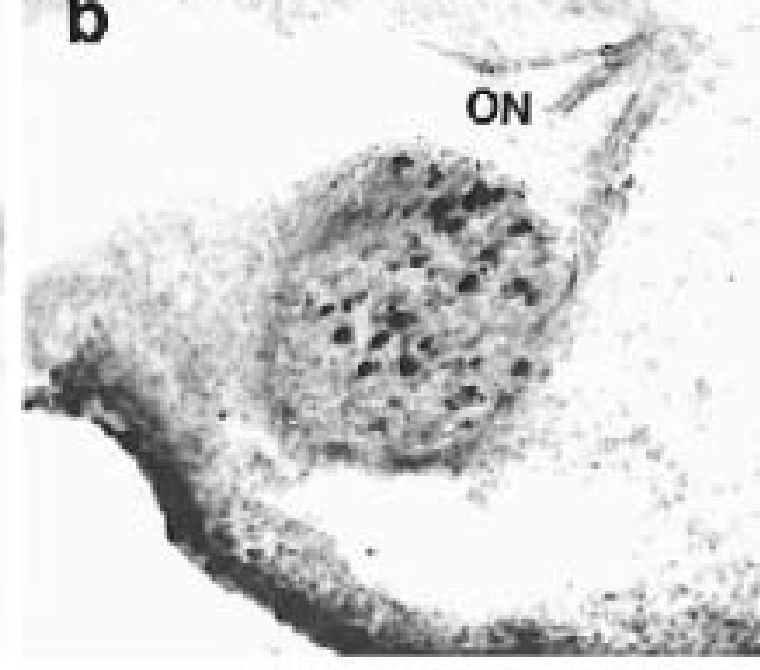

arisines

\section{7}

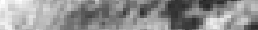
(a)
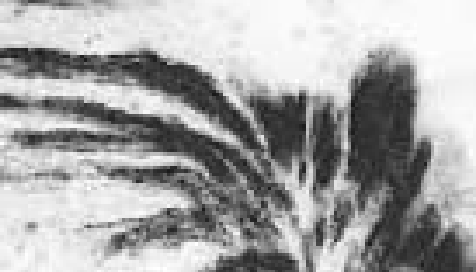

.
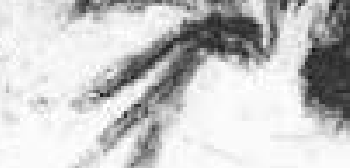


\section{a}

66
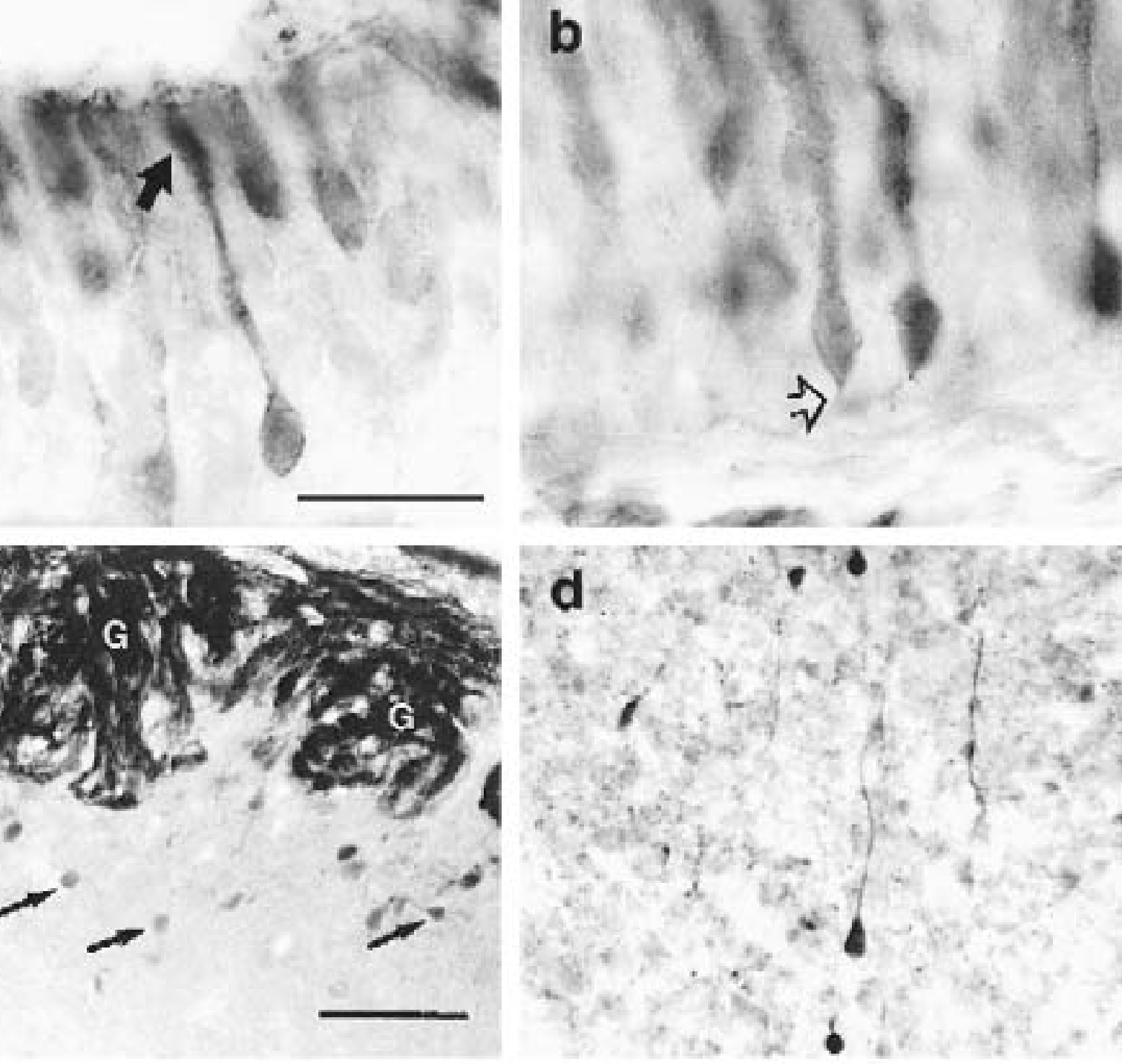

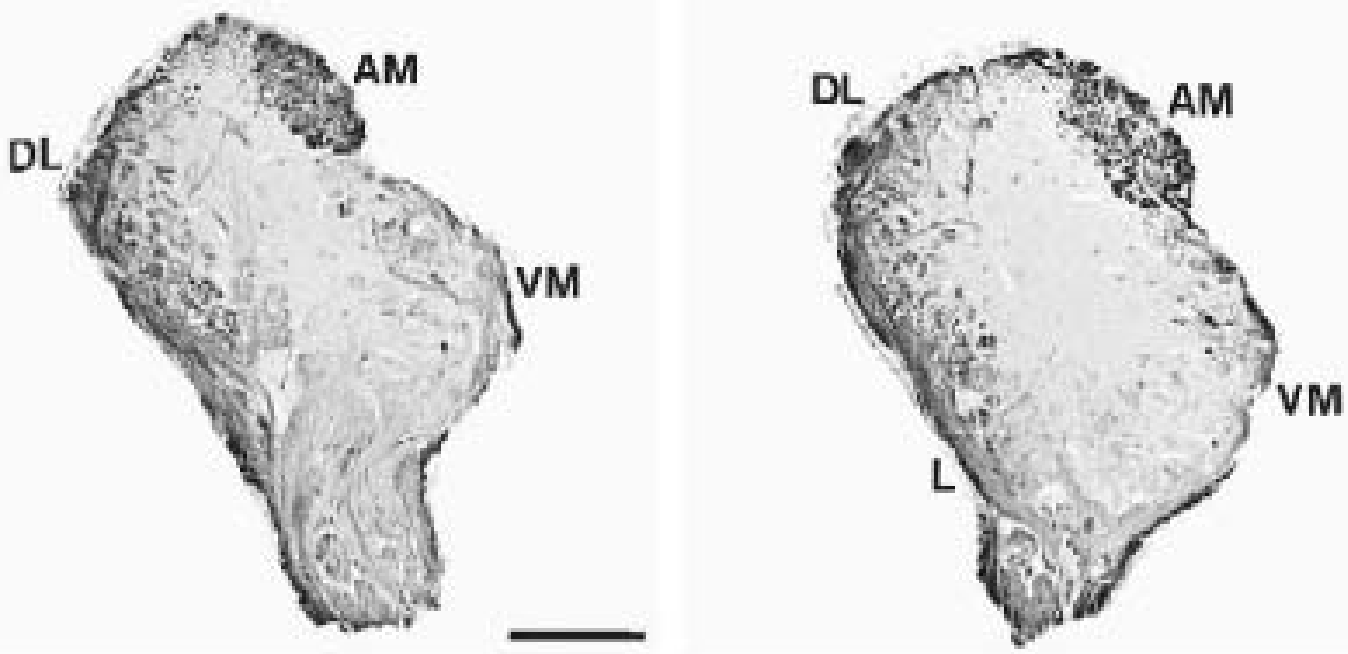
VP
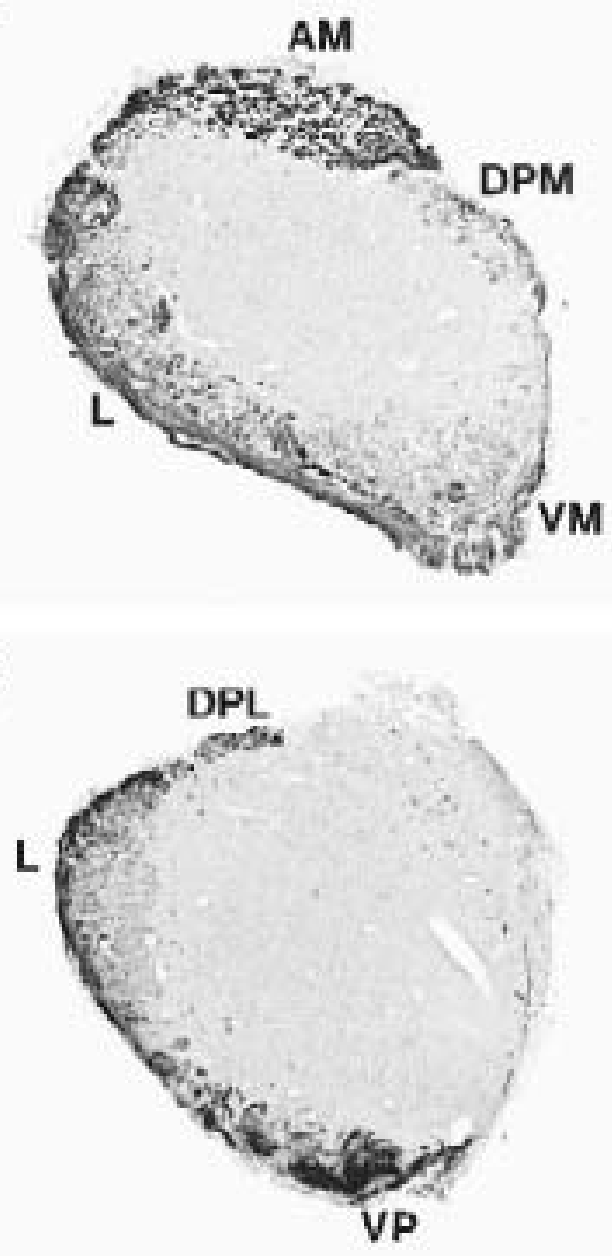

C

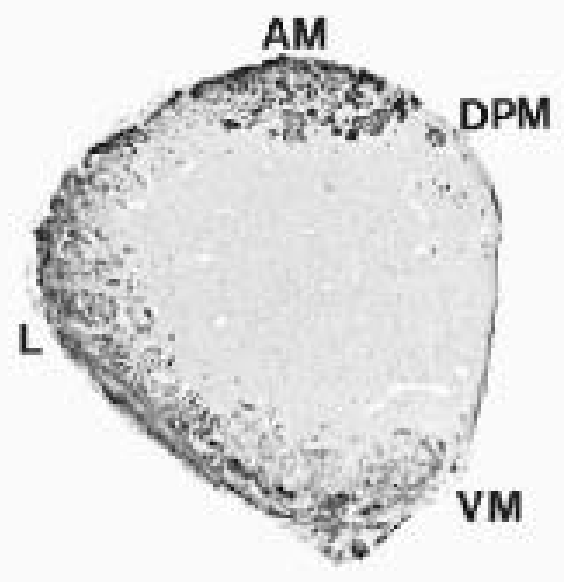

f

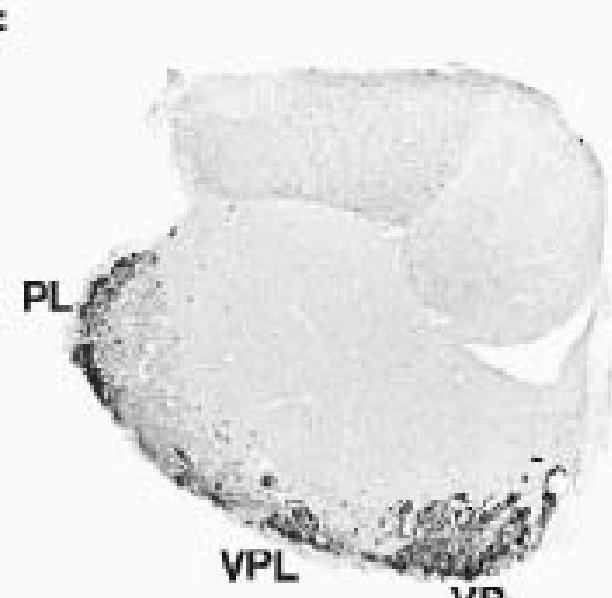

d

f 